Al-Amwal: Jurnal Ekonomi dan Perbankan Syariah

ISSN: 2303-1573 e-ISSN: 2527-3876

Homepage: https://www.syekhnurjati.ac.id/jurnal/index.php/amwal email: jurnalalamwal@syekhnurjati.ac.id

\title{
The Effect of Exchange Rate, Jakarta Islamic Index(JII)and Indonesian Sharia Bank Certificate (SBIS) on Islamic Mutual Funds Growth with Inflation as a Moderate Variable
}

\author{
Musalim Ridlo \\ Program PascasarjanaEkonomiSyariahIAIN Salatiga \\ Alumnus FakultasEkonomidanBisnis Islam, IAIN Salatiga \\ e-mail:Gusmusa19@gmail.com \\ Tri Yunianto \\ Program PascasarjanaEkonomiSyariahIAIN Salatiga \\ Alumnus FakultasEkonomidanBisnis Islam, IAIN Salatiga \\ ImaniaAnisya Rohmah \\ Program PascasarjanaEkonomiSyariahIAIN Salatiga \\ Alumnus FakultasEkonomidanBisnis Islam, IAIN Salatiga
}

\begin{abstract}
This study aims to analyze the influence of exchange rate, Jakarta Islamic Index, Indonesian Shari Bank Certificate towards the growth of Islamic mutual funds with Inflation as a moderate variable in Indonesia period 2014-2018. This study uses a quantitative approach using a secondary data type with time series model. Furthermore, the data were tested using multiple linear regression models and moderated regression analysis (MRA) through EVIEWS 9 statistical application. The results of this study indicate that the variable exchange rate has a significant negative effect on the growth of Islamic mutual funds, Jakarta Islamic index has a significant positive effect, inflation has no significant negative effect, and Indonesian sharia bank certificate has no significant effect on the growth of Islamic mutual funds. The variable inflation is able to moderate Jakarta Islamic index, but can't moderate variable exchange rate and Indonesia sharia bank certificate on the growth of Islamic mutual funds.
\end{abstract}

Keywords: Exchange Rate, Jakarta Islamic Index (JII), Bank Indonesian Sharia Certificate (SBIS), Inflation, Islamic Mutual Funds. 


\begin{abstract}
Abstrak
Penelitianini bertujuan untuk menganalisis pengaruh nilai tukar, Jakarta Islamic Index, Sertifikat Bank Syariah Indonesia terhadap pertumbuhan reksadana syariah dengan inflasi sebagai variable moderat di Indonesia periode 2014-2018. Penelitian ini menggunakan pendekatan kuantitatif dengan jenis data sekunder dengan model runtun waktu. Selanjutnya data diuji dengan menggunakan model regresi linier berganda dan analisis regresi moderasi (MRA) melalui aplikasi statistik EVIEWS 9. Hasil penelitian ini menunjukkan bahwa variabel nilai tukar berpengaruh negatif signifikan terhadap pertumbuhan reksadana syariah, Jakarta Islamic index berpengaruh positif signifikan, inflasi tidak berpengaruh negatif signifikan, dan sertifikat bank syariah Indonesia tidak berpengaruh signifikan terhadap pertumbuhan reksadana syariah. Variabel inflasi mampu memoderasi indeks syariah Jakarta, tetapi tidak dapat memoderasi variable nilai tukar dan sertifikat bank syariah Indonesia terhadap pertumbuhan reksadana syariah.
\end{abstract}

Kata kunci: Nilai Tukar, Jakarta Islamic Index (JII), Sertifikat Bank Indonesia Syariah (SBIS), Inflasi, Reksa Dana Syariah.

\title{
INTRODUCTION
}

Sharia mutual funds are a place to conduct investment transactions for the public by Islamic law. In sharia mutual funds there is a cleaning process, which is cleaning up the property from illicit elements such as usury and others. This, as well as being the difference between conventional and Islamic mutual funds (Lestari, 2015). The development of Islamic mutual funds in Indonesia continues to experience significant growth, this indicates that the public has begun to realize by switching to using Islamic mutual funds in investing. As reported by the Financial Services Authority (OJK), the following is the development of Islamic mutual funds from 2014 to 2018 (www.ojk.go.id);

Table 1 Development of Sharia Mutual Funds in Indonesia

\begin{tabular}{ccc}
\hline Year & Number of Sharia Mutual Funds & Total NAB yoy (Rp Miliar) \\
\hline $\mathbf{2 0 1 4}$ & 74 & $11.158,00$ \\
$\mathbf{2 0 1 5}$ & 93 & $11.019,43$ \\
$\mathbf{2 0 1 6}$ & 136 & $14.914,63$ \\
$\mathbf{2 0 1 7}$ & 182 & $28.311,77$ \\
$\mathbf{2 0 1 8}$ & 224 & $34.491,17$ \\
\hline
\end{tabular}

Source:(www.ojk.go.id)

The growth of Islamic mutual funds in Indonesia occurs because of factors that affect both directly and indirectly. In this study, the factors that are suspected to influence the net asset value of sharia mutual funds are the Exchange Rate, Jakarta Islamic Index (JII), Bank Indonesia Sharia Certificate (SBIS), and inflation. Exchange rates are foreign exchange or foreign exchange reserves held by the Central Bank in each country. Exchange rates occur due to the accumulation of surpluses in the balance of payments continuously. This will increase the number of foreign exchange rates owned by a country (Maurya, 2017). As research conducted by Utami (2017);Nandari (2017), which says that the exchange rate can affect the growth of Islamic mutual funds.MeanwhileShofia (2018); Adrian \& Rachmawati (2019), said that the exchange rate did not have a significant effect on Islamic mutual funds. 
Jakarta Islamic Index (JII) is one of the stock indexes in Indonesia that calculates the average stock price index for stocks that meet the sharia criteria (Fitriyani, 2012). As research conducted by Shofia (2018), which says that Jakarta Islamic Index (JII) can affect the growth of Islamic mutual funds. MeanwhileChairani (2020), said the Jakarta Islamic Index (JII) had no significant effect on the growth of Islamic mutual funds.

Bank Indonesia Sharia Certificates (SBIS) are securities based on short-term sharia principles in rupiah currency issued by Bank Indonesia (www.bi.go.id). As research conducted by Kasyfurrahman \& Beik (2012), which says that the Bank Indonesia Sharia Certificates (SBIS) can affect the growth of Islamic mutual funds. Meanwhile Nafisah \& Supriyono (2020), said that inflation does not have a significant effect on the growth of Islamic mutual funds.

Inflation can be defined as a general increase in the price level of goods and services at a certain time (Akinsola \& Odhiambo, 2017). As research conducted by Shofia (2018); Nandari (2017), which says that the inflation can affect the growth of Islamic mutual funds. Meanwhile Rachman \& Mawardi(2015), said that inflation does not have a significant effect on the growth of Islamic mutual funds.

The purpose of this study in addition to knowing and analyzing is also to answer from the formulation of the problem namely how the influence of the exchange rate, the Jakarta Islamic Index, Bank Indonesia Sharia Certificates and inflation on the growth of Islamic mutual funds and how the influence of the exchange rate, the Jakarta Islamic Index and Bank Indonesia Sharia Certificates on mutual fund growth sharia which is moderated by inflation.

\section{LITERATURE REVIEW Signaling Theory}

Signal is a company action taken to provide information to investors regarding how the company's prospects are managed. This information contains information, notes or descriptions, both for past, present and future conditions for the survival of the company (Brigham \& Houston, 2001).In addition, the signaling theory states that dividend policy is an interpretation of managers' expectations regarding the company's future cash flows and market reactions to dividend payment information (Abdullah, 2002).

\section{Sharia Mutual Fund}

Sharia mutual funds are a place for people to invest their funds through investment managers to invest in securities portfolios, where operations are in accordance with the principles of Islamic law, both in terms of contracts between investors and investment managers and investment managers and other parties. (Khalijah, 2017).

\section{Exchange Rate}

The exchange rate is a comparison of the currency value of a country with other countries. Changes in exchange rates can affect the company's competitiveness, where exchange rate fluctuations affect the company's revenue and operating costs (Ilmi, 2017).

\section{Jakarta Islamic Index (JII)}

JII is one of the stock indexes in Indonesia which operates according to sharia principles. The establishment of Islamic instruments aims to support the Islamic capital 
market in Indonesia which was launched on March 14, 2003 (Utami \& Herlambang, 2016).In addition, JII is one of the benchmarks for the performance of the Islamic stock index, in terms of the dominant product choices for investing in the form of Islamic mutual funds. Benchmarks or benchmarks have been commonly used to assess the performance of investment managers in managing funds (Sudjaja \& Berlian, 2003).

\section{Bank Indonesian Sharia Certificate (SBIS)}

Based on Bank Indonesia regulation Number: 10/11 / PBI / 2008, Bank Indonesia Sharia Certificates are short-term securities based on sharia principles in the rupiah currency issued by Bank Indonesia. . Bank Indonesia Syariah Certificates as an open market operating instrument for monetary control implemented based on sharia principles (www.dsnmui.or.id).

\section{Inflation}

Inflation is defined as a general continuous increase in the price of goods and services at a certain time (Akinsola \& Odhiambo, 2017).In general, high and low inflation affects economic growth, especially in the financial sector (Sumon \& Miyan, 2017), one of which is the capital market.

\section{Theoretical Model Frameworks}

In this section the authors propose a research framework that is taken based on the background of the problem and the results of theoretical studies as well as from previous research. Then the research framework is as follows:

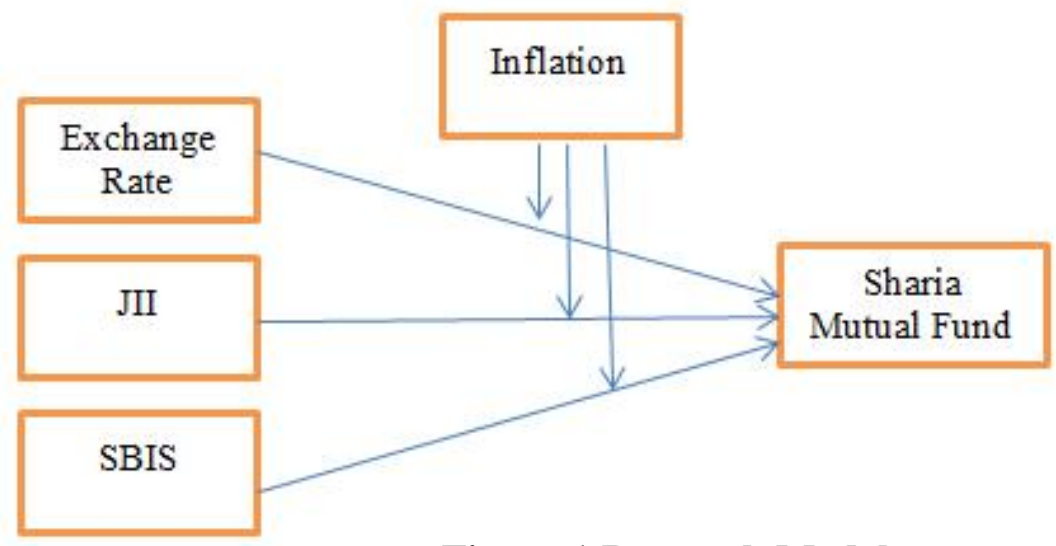

Figure 1 Research Model

From Figure 1, it can be explained that inflation can strengthen or weaken the influence of the three independent variables, namely the exchange rate, the Jakarta Islamic Index, and the Bank Indonesia Syariah Certificate on the Growth of Sharia Mutual Funds.

\section{Hypotheses}

\section{The Impact of Exchange Rate on Sharia Mutual Fund Growth}

As research conducted by Rachman \& Mawardi (2015);Adrian \& Rachmawati (2019),stated that inflation has a negative and significant effect on NAV of Islamic mutual funds. If the rupiah exchange rate decreases, the debt to be paid will increase, investment will decrease so that the company's performance also decreases as a result of the decline in stock prices and an impact on the decrease in the NAV of Islamic mutual funds. Based on those, it is hypothesised that:

H1: Exchange Rate has a negative and significant on Sharia Mutual Fund Growth 


\section{The Impact of Jakarta Islamic Index (JII)on Sharia Mutual Fund Growth}

As research conducted by Darmawan \& Nada (2019); Chairani (2020),stated that the Jakarta Islamic Index has a positive and significant influence on the growth of Islamic mutual funds. This is because the Jakarta Islamic Index is an indicator to see the activity of the capital market and almost all Islamic mutual funds are invested in stocks that are included in the Islamic index. So that if the investment performance in shariabased stocks will certainly increase the amount of net asset value / Islamic mutual fund units.Based on those, it is hypothesised that:

H2: Jakarta Islamic Index has a positive and significant on Sharia Mutual Fund Growth

The Impact of Bank Indonesian Sharia Certificate (SBIS) on Sharia Mutual Fund Growth

As research conducted by Alghifari et al. (2019); Nafisah \& Supriyono (2020), states that the Bank Indonesia Sharia Certificate has a positive and insignificant relationship. This means that the level of profit sharing in the Bank Indonesia Syariah Certificate does not affect investors in determining their investment choices in Islamic mutual funds. In addition, most Islamic mutual funds are not invested in money market instruments (in the form of Bank Indonesia Syariah Certificates) but in the form of shares. While the research conducted by Addina (2018), found that Bank Indonesia Sharia Certificates had no effect on Islamic mutual funds because the bonus level of Bank Indonesia Syariah Certificates did not significantly affect Islamic mixed mutual funds. Based on those, it is hypothesised that:

H3: Bank Indonesian Sharia Certificate has a positive and no significant on Sharia Mutual Fund Growth

\section{The Impact of Inflation on Sharia Mutual Fund Growth}

A research conducted by Rani \& Syaharuddin (2015); Sahri et al.(2015); Nafisah \& Supriyono (2020); Amzal (2016); Sumantyo \& Savitri (2019),states that the inflation variable has a negative and significant effect on the net asset value of Islamic mutual funds, meaning that any increase in inflation will cause a decrease in the net asset value of Islamic mutual funds. This is consistent with the fact that when experiencing inflation, people will reduce their investment or even not invest because their income is used to meet needs whose prices have increased.Based on those, it is hypothesised that:

H4: Inflationhas a negative and significant on Sharia Mutual Fund

\section{The Impact of Inflation on the Relationship between Exchange Rate on Sharia Mutual Fund Growth}

According to Mankiw (2003), inflation can affect a country's economy through income, wealth and through changes in the rate and efficiency of products. While the research conducted byAwaluddin (2011), explains that inflation increases company revenues and costs. If the increase in production costs is higher than the increase in prices that can be enjoyed by the company, the company's profitability will decrease, marked by a decrease in the price of securities which then reduces the net asset value of 
Islamic mutual funds, and vice versa. This is in accordance with the APT theory which explains that inflation is one of the factors that can affect stock prices and can affect the state of a company (Belkaoui, 2007).

The relationship of exchange rates moderated by inflation to Islamic mutual funds is explained in research from Mardhiyah (2017), that the variable exchange rate or rupiah exchange rate moderated by inflation has a significant effect on stock prices. If inflation increases, it will reduce the demand for money so that stock prices will decline. Likewise, if the rupiah exchange rate weakens, it will affect the stock price in Islamic mutual funds.Based on those, it is hypothesised that:

H5: Inflation is able to moderate the relationship between Exchange Rate on Sharia Mutual Fund Growth

\section{The Impact of Inflation on the Relationship between Jakarta Islamic Index (JII) on Sharia Mutual Fund Growth}

A research conducted by Mardhiyah (2017), stated that the influence of JII on the growth of Islamic mutual funds which is moderated by inflation has a significant effect. This means that if inflation increases, investors will withdraw their capital in the Jakarta Islamic Index or in companies listed in the Jakarta Islamic Index, this also affects Islamic mutual funds investing in the Jakarta Islamic Index. Based on those, it is hypothesised that:

H6: Inflation is able to moderate the relationship between Jakarta Islamic Index on Sharia Mutual Fund Growth

\section{The Impact of Inflation on the Relationship between Bank Indonesian Sharia Certificateon Sharia Mutual Fund Growth}

Bank Indonesia Sharia certificates or SBIS are used by Bank Indonesia to control inflation in Indonesia. If inflation increases, Bank Indonesia will issue an SBIS policy to control inflation by increasing the profit sharing from the Bank Indonesia Sharia Certificate auction. So it can be interpreted that if inflation rises, the Bank Indonesia Sharia Certificate will also increase (Perlambang, 2010).

When Indonesian Bank (BI) issues Bank Indonesia Sharia Certificates and sells it to the public it will cause the amount of money circulating in the community to decrease. The decline in Money supply (JUB) is one of the targets to be achieved in the setting of contractive policies. Where the economy goes too strong and causes inflation (Raharjo, 2004).Based on those, it is hypothesised that:

H7: Inflation is able to moderate the relationship between Bank Indonesian Sharia Certificate on Sharia Mutual Fund Growth 


\section{METHOD}

This type of research is quantitative research. Quantitative research is research conducted by collecting data in the form of data numbers, then processed and analyzed to obtain a scientific information behind these numbers (Martono, 2011). Data obtained from the Financial Services Authority (OJK) via www.ojk.go.idIndonesia Stock Exchange through www.yahoofinance.co.id Bank Indonesia through www.bi.go.id and the Ministry of Trade of the Republic of Indonesia through www.kemendag.go.id. The data used from January 2014 to December 2018 include the Net Asset Value of Sharia Mutual Funds, Exchange Rate Data against US Dollar, Jakarta Islamic Indexdata, Inflation data, and SBIS data.

\section{Sample Procedure}

According to Bawono (2006), samples are objects or subjects that are taken from the population to represent the entire population. Each variable is taken monthly data from 2014-2018, so that the total sample is 300 samples. This study uses a saturated sample technique or also known as a census sample. Census saturated sampling is a sampling technique when all members of the population are used as samples. The samples used in this study were all inflation data, exchange rates, the Jakarta Islamic Index, and Bank Indonesia Syariah Certificates.

\section{Analysis Technique}

This study uses multiple linear regression analysis and moderated regression analysis (MRA). Moderated Regression Analysis (MRA) is a special application of multiple linear regression, where the regression equation contains interaction elements, namely multiplication between two or more independent variables (Ghozali, 2011).

\section{RESULT AND DISCUSSION Regression Analysis}

In this case, Ghozali (2018), said that:

"In general, regression analysis is basically a study of the dependence of the dependent variable (bound) with one or more independent variables (independent variables), with the aim of estimating and / or predicting the population average or the average value of the dependent variable based on the value of the independent variable the known".

Table 1 Regression Analysis Test Result

\begin{tabular}{lll}
\hline \multicolumn{1}{c}{ Variable } & t-statistic & Prob. \\
\hline Exchange rate (X1) & -0.91 & 0.36 \\
Jakarta Islamic Index (X2) & -1.18 & 0.23 \\
Bank Indonesia Sharia Certificate (X3) & 1.52 & 0.13 \\
Inflation (Z) & -1.08 & 0.28 \\
Exchange rate> Inflation & 1.02 & 0.31 \\
Jakarta Islamic Index>-inflation & 2.12 & 0.03 \\
Bank Indonesia Sharia Certificate> Inflation & -0.45 & 0.65 \\
\hline Dependent Variable: Sharia Mutual Fund (Y) & &
\end{tabular}

Based on the test results in Table 1, shows the resulting output shows that the variable exchange rate (KURS,2) had no significant negative effect with the coefficient value is - 
1.049248 and prob.* value is $0.3637>$ alpha 0.05 . Variable Jakarta Islamic Index (JII,2) had no significant negative effect with the coefficient value is -20.00059 and prob.* value is $0.2398>$ alpha 0.05. Variable Bank Indonesia Sharia Certificates (SBIS,2) had no significant positive effect with the coefficient value is 2248.652 and prob.* value is 0.1336 and variable inflation had no significant negative effect with the coefficient value is -6053.134 and prob.* value is 0.2850 .

\section{Moderated Regression Analysis (MRA)}

The moderating variable functions to strengthen or weaken the relationship between the independent variable and the dependent variable (Bryan \& Haryadi, 2018).

Table 2 Multiple Regression Test

\begin{tabular}{lll}
\hline R-square & Adjusted r-square & Prob. (F-statistic) \\
\hline $\mathbf{0 . 2 0 7}$ & 0.147 & 0.013 \\
\hline
\end{tabular}

Table 3 Moderated Regression Analysis (MRA) Test Results

\begin{tabular}{lll}
\hline R-square & Adjusted r-square & Prob. (F-statistic) \\
\hline $\mathbf{0 . 3 0 6}$ & 0.209 & 0.007
\end{tabular}

From table 2 and table 3, it can be seen that the adjusted $\mathrm{R}^{2}$ value is 0.147283 in table 2 , to 0.209702 in table 3 . This means that there is a moderating variable that is Inflation can increase the value of adjusted $\mathrm{R}^{2}$ before in table 2. Furthermore, in table 2 also obtained the $\mathrm{F}$ test in this study has a coefficient value of 3.461281 with prob. * (Fstatistics) of $0.013840<0.05$. These results indicate that all independent variables together influence the dependent variable, Sharia Mutual Funds.

\section{Discussion}

\section{The Effect of Exchange Rates on the growth of Islamic Mutual Funds}

The Exchange rate variables indicate the alpha coefficient 5\% Coefficient value $=-1.049248$ and Prob. $* 0.3637>0.05$. Then it means that the exchange rate variable has a negative and not significant effect on the growth of Sharia Mutual Funds at alpha $5 \%$ because the results of this study are not by the hypothesis presented, $\mathrm{H} 1$ is rejected. This is because the ups and downs of the USD exchange rate do not affect investor interest in investing in sharia mutual fund instruments.

The results of this study are not supported by Rachman \& Mawardi (2015), which explained that the exchange rate had a negative and significant effect on Sharia Mutual Funds. Where if the rupiah exchange rate decreases the debt to be paid will increase, investment decreases so that the company's performance also decreases. While the result of this research is supported by which in his research stated that the Exchange Rate had a negative and insignificant effect because the development of the rupiah exchange rate was relatively stable and reasonable. Then there are still few instruments in sharia mutual funds that contain foreign investment instruments so that the changes that occur in the development of the rupiah exchange rate against the USD are not too influential for the growth of Sharia Mutual Funds.

The Effect of the Jakarta Islamic Index on the Growth of Islamic Mutual Funds

The Jakarta Islamic Index (JII) variable shows the alpha coefficient 5\% Coefficient $=15.46031$ and Prob. $* 0.0206<0.05$. Then it means the Jakarta Islamic Index (JII) variable has a positive and significant effect on the growth of Sharia Mutual 
Funds at alpha 5\%. So, it can be interpreted that the size of the Jakarta Islamic index (JII) will significantly influence the growth of sharia mutual funds.

The results of this study are supported byShofia (2018), where the results of his research indicate that the Jakarta Islamic Index (JII) variable has a negative and significant effect on the growth of Sharia Mutual Funds which can be seen from the increase in Net Asset Value (NAV). Then the increase in the index value on the Jakarta Islamic Index (JII) will increase the NAV of sharia mutual funds, especially mutual funds whose portfolios are on stock items in the capital market.

\section{The Effect of Bank Indonesia Sharia Certificates (SBIS) on the Growth Sharia Mutual Fund}

SBIS variable shows the alpha coefficient 5\% Coefficient value $=1791,781$ and Prob. * $0.0421<0.05$. Then it means that the SBIS variable has a positive and significant effect on the growth of Sharia Mutual Funds at alpha 5\%. So, it can be interpreted that the size of the SBIS level will significantly influence the growth of sharia mutual funds.

A research conducted by Kasyfurrahman \& Beik (2012), where several indicators that influence the growth of Islamic mutual funds such as, Indonesian securities (SBI), SBIS, Exchange rates, inflation, CSPI and JII.SBIS did not have a significant effect on the growth of sharia mutual funds. This is mainly due to the high and low levels of profit sharing of Bank Indonesia Sharia Certificates (SBIS) that do not affect investors in determining their investment choices in sharia mutual funds, besides sharia mutual funds are mostly invested nuances in the form of money market instruments and investors do not pay attention to Bank Indonesia Certificates Sharia (SBIS) when investing in Sharia Mutual Funds.

\section{The Effect of Inflation on the Growth of Islamic Mutual Funds}

Inflation variable shows the alpha coefficient 5\% Coefficient value $=458.7588$ and Prob. $* 0.0391<0.05$. Then it means that the inflation variable has a positive and significant effect on the growth of Sharia Mutual Funds at alpha 5\%. So, it can be interpreted that the size of the inflation rate will significantly influence the growth of Islamic mutual funds.

As research conducted by Rani \& Syaharuddin (2015);Sahri et al.(2015); Nafisah \& Supriyono (2020); Amzal (2016); Sumantyo \& Savitri(2019), where the results of the study indicate that inflation has a positive and significant effect on the growth of sharia mutual funds as seen from the increase in Net Asset Value (NAV). That can be caused because when inflation is high as evidenced by rising prices in the real sector that will affect both directly and indirectly on the capital market. Investors will choose to save funds in the bank or invest in mullah metals such as gold.

The results of the study are not supported by (Rachman \& Mawardi, 2015), where the results of the study indicate that inflation does not affect the growth of Islamic mutual funds. That can be because investors consider the real return rather than inflation that occurred in that year. So each asset has a product character, risk, potential return, and the ideal investment period of each. In order not to be affected by inflation, it is better to take investment instruments whose return is higher than inflation. For example, in one year there was inflation of $7 \%$, investors will invest in companies whose returns exceed inflation. And bond mutual funds, mixed mutual funds, and equity funds are included in investment instruments that are able to surpass inflation (www.sam.co.id). 


\section{The Effect of Inflation in Moderating the Relationship between the Exchange Rate}

and the Growth of Islamic Mutual Funds

The exchange rate><inflation variable shows the alpha coefficient $5 \%$ Coefficient value $=0.215027$ and Prob. $* 0.3105>0.05$. Then it means that the variable exchange rate><inflationhas a positive and not significant effect on the growth of Sharia Mutual Funds at 5\% alpha. This means that the inflation variable is not able to strengthen the relationship between the exchange rate and the growth of Islamic mutual funds.

In this case, even though the inflation rate affects the exchange rate or the exchange rate, as research conducted byWijayanti \& Sudarmiani (2017), however, this has not been able to change the effect of the exchange rate on the growth of Islamic mutual funds. One of the reasons is because if the rupiah exchange rate decreases the debt to be paid will increase, investment decreases so that the company's performance also decreases.

\section{The Effect of Inflation in Moderating the Relationship between the Jakarta Islamic Index and the Growth of Islamic Mutual Funds}

The Jakarta Islamic Index><inflation variable shows the alpha coefficient 5\% Coefficient value $=7.063975$ and Prob. $* 0.0388<0.05$. Then it means that the Jakarta Islamic Index $><$ inflation variable has a positive and significant effect on the growth of Sharia Mutual Funds at alpha 5\%. This means that in this case inflation can strengthen the relationship between the influence of the Jakarta Islamic Index on the growth of Islamic mutual funds.

As research conducted by (Mardhiyah, 2017), states that inflation and the Jakarta Islamic Index (JII) simultaneously affect the performance of Islamic mutual funds. That way inflation can strengthen the influence of the Jakarta Islamic Index (JII) with Sharia Mutual Fund Growth. Because in this case almost all shares in Sharia Mutual Funds.

\section{The Effect of Inflation in Moderating the Relationship between the Bank Indonesia} Sharia Certificate and the Growth of Islamic Mutual Funds

The Bank Indonesia Sharia Certificate $><$ inflation variable shows the 5\% alpha coefficient $=-158.0155$ and Prob. $* 0.6512>0.05$. Then it means that the Bank Indonesia Sharia Certificate $><$ inflation variable has a negative and not significant effect on the growth of Sharia Mutual Funds at alpha 5\%. It was concluded that inflation was not able to strengthen the influence of Bank Indonesia Sharia Certificates (SBIS) on the Growth of Sharia Mutual Funds. If the inflation rate is high, it will cause prices to rise which also affects the monetary sector such as the Islamic capital market. People prefer to save their funds rather than invest when inflation occurs.

\section{CONCLUSION}

Based on the test data and the conclusions from the discussion the research conclusions can be obtained, as follows: (1) Exchange rates have a negative and not significant effect on the growth of Islamic mutual funds. (2) Jakarta Islamic Index (JII) has a positive and significant effect on the growth of sharia mutual funds. (3) Bank Indonesia Sharia Certificates (SBIS) have a positive and significant effect on the growth of sharia mutual funds. (3) Inflation has a positive and significant effect on the 
growth of sharia mutual funds. (4) Inflation cannot moderate the relationship between the exchange rate and the growth of sharia mutual funds. (5) Inflation is able to moderate the relationship between the Jakarta Islamic Index (JII) to the growth of Islamic mutual funds. (6) Inflation cannot moderate the relationship between Bank Indonesia Sharia Certificates (SBIS) to the growth of sharia mutual funds.

From the results of this study, there are several options that might be important in establishing the policy in term of increasing the Islamic mutual funds growth in Indonesia. Frist, as effort to increasing Islamic mutual funds, the government should to make rules that make it easier for investors to invest in the mutual fund sector, such as keeping inflations level below standard and increasing profit sharing. Second, provide strict sanctions for those who violate investment rules etc. This study uses a short period of time so that the results obtained are less than optimal. It is expected that further research will add independent variables that are still relevant such as IHSG, JUB, GDP, and others.

\section{REFERENCES}

Abdullah, P. (2002). Daya Saing Daerah: Konsep dan Pengukurannya Di Indonesia. BPFE.

Adrian, M., \& Rachmawati, L. (2019). Pengaruh Inflasi Dan Nilai Tukar Rupiah Terhadap Nilai Aktiva Bersih Reksadana Syariah. Jurnal Ekonomi Islam, 2(1).

Akinsola, F. A., \& Odhiambo, N. M. (2017). Inflation and Economic Growth : a Review of The International Literature. Comparative Economic Research, 20(3), 41-56.

Alghifari, M., Akmal, C., \& Wulandari, S. (2019). Pengaruh Inflasi Dan Sertifikat Bank Indonesia Syariah Terhadap Perkembangan Reksadana Syariah Tahun 20152018.TAZKIYA Jurnal Keislaman, Kemasyarakatan Dan Kebudayaan, 20(01).

Amzal, C. (2016). The Impact Of Macroeconomic Variables On Indonesia Islamic Banks Profitability. Jurnal Ekonomi Dan Bisnis Islam, 2(1).

Awaluddin, Z. (2011). Pengaruh Profitabilitas terhadap Return Saham dan Inflasi sebagai Variabel Moderasi pada Perusahaan Manufaktur di Bursa Efek Indonesia Tahun 2005-2009. Universitas Negeri Semarang.

Bawono, A. (2006). Multivariabel Analisis dengan SPSS. STAIN Salatiga Press.

Belkaoui, A. R. (2007). Accounting Theory (5th Editio). Salemba Empat.

Brigham, F., \& Houston, J. (2001). Dasar-Dasar Manajemen Keuangan (Edisi 8). Salemba Empat.

Bryan, \& Hryadi, E. (2018). Analisis Pengaruh Variabel Moderasi Switching Costs Terhadap Hubungan Service Performance Dan Customer Loyalty Member Celebrity Fitness Jakarta. Jurnal Manajemen, 15(1), 52-71.

Chairani, S. (2020). Pengaruh Nilai Tukar Rupiah ( Kurs ), Jakarta Islamic Index (JII), Usia Reksadana , Dan Volume Perdagangan Reksadana Terhadap Nilai Aktiva Bersih ( Nab ) Reksadana Campuran Syariah. 15(1), 31-43.

Darmawan, \& Nada, L. (2019). Fund Age, BI Rate, Exchange Rate, dan Jakarta Islamic Index Pada Net Asset Value Di Islamic Equity Mutual Fund Indonesia. Jurnal Manajemen, 10(1), 1-11.

Fitriyani. (2012). Analisa Pengaruh Krisis Global Financial Terhadap Jakarta Islamic Index Dan Index Harga Saham Gabungan (IHSG). Jurnal Ekonomi Dan Keuangan Islam, 2(1), 2-12.

Ghozali, I. (2011). Aplikasi Analisis Multivariate dengan Program IBM SPSS 19. Badan 
Penerbit Universitas Diponegoro.

Ghozali, I. (2018). Aplikasi Analisis Multivariate dengan program IBM SPSS 25 edisi 9. Badan Penerbit Universitas Diponegoro.

Ilmi, M. F. (2017). Pengaruh Kurs/ Nilai Tukar Rupiah, Inflasi Dan Tingkat Suku Bunga Sbi Terhadap Indeks Harga Saham Gabungan Lq-45 Periode Tahun 20092013. JURNAL NOMINAL, VI(1).

Kasyfurrahman, A., \& Beik, I. S. (2012). Pengaruh Makroekonomi Terhadap Reksadana Syariah. Iqtishodia Jurnal Ekonomi Islam Republika.

Khalijah, S. (2017). Reksa Dana Syariah. AL-INTAJ, 3(2).

Lestari, W. R. (2015). Kinerja Reksadana Saham Syariah Dan Reksadana Saham Konvensional. Urnal Magister Manajemen, 1(1), 116-128.

Mankiw, N. G. (2003). Teori Makro Ekonomi. Erlangga.

Mardhiyah, N. A. (2017). nalisis Pengaruh Kurs, Indeks Harga Saham Gabungan, Jakarta Islamic Index Dan Jumlah Uang Beredar Terhadap Nilai Aktiva Bersih Reksadana Syariah Di Indonesia Dengan Inflasi Sebagai Variabel Moderasi Pada Periode 2012-2016. IAIN Salatiga.

Martono, N. (2011). Metodologi Penelitian Kuantitatif Analisis Isi dan Analisis Data Sekunder. PT RajaGrafindo Persada.

Maurya, S. (2017). Factor Affecting Exchange Rate and Its Impact on Economy in India. Asian Journal of Research in Business Economics and Management, 7(8), 324-347.

Nafisah, H., \& Supriyono. (2020). Analysis of the Effect of Macroeconomics on Net Assets Value (NAV) of Sharia Mutual Funds in Indonesia. 4(1), 11-20.

Nandari, H. U. (2017). Pengaruh Inflasi Kurs Dan BI Rate Terhadap Nilai Aktiva Bersih (NAB) Reksadana Syariah Di Indonesia Periode 2010-2016. Jurnal An Nisbah, 4(1), 51-73.

Perlambang, H. (2010). Analisi Pengaruh Jumlah Uang Beredar, Suku Bungan SBI, Nilai Tukar Terhadap Tingkat Inflasi. Media Ekonomi, 19(2).

Rachman, A., \& Mawardi, I. (2015). Pengaruh Inflasi, Nilai Tukar Rupiah, BI Rate Terhadap Net Asset Value Reksadana Saham Syariah. Jurnal UNAIR, 2(12).

Raharjo, S. (2004). Panduan Investasi Reksa Dana. Pilihan Bijak Berinvestasi \& Mengembangkan Dana. Elex Media Komputindo.

Rani, A., \& Syaharuddin. (2015). Determinan Total Nilai Aktiva Bersih Danareksa Syariah Berimbang Pada PT Danareksa Investment Managemen : Apakah Inflasi Berpengaruh. Jurnal Ekonomi.

Sahri, S., Seto, A. A., \& Syahyuni. (2015). Comparative Performance Analysis Of Sharia Mutual Funds In Indonesia Stock Exchange And Malaysia Exchange (Approach To Exchange, Inflation And Interest Rates).International Seminar FEUM 2015 Reorienting Economics \& Business in The Context of National and Global Development, ISSN 2460-0296.

Shofia, G. K. (2018). Analisis Pengaruh Jakarta Islamic Index (JII), Nilai Tukar Rupiah Dan Inflasi Terhadap Nilai Aktiva Bersih Reksadana Syariah Campuran Periode 2014-2016. Jurnal Hukum Ekonomi Syariah, 4(2).

Sudjaja, R. S., \& Berlian, I. (2003). Manajemen Keuangan. Literata Lintas Media.

Sumantyo, R., \& Savitri, D. A. (2019). Macroeconomic variables towards net asset value of sharia mutual funds in Indonesia and Malaysia. 23(2), 300-307.

Sumon, K. K., \& Miyan, S. (2017). Inflation and Economic Growth: An Empirical Evidence of. 7(5), 454-464. 
Utami, A. T., \& Herlambang, L. (2016). Pengaruh Variabel Makro Ekonomi Terhadap Indeks Jakarta Islamic Index (Jii) Periode Januari 2010 Hingga November 2015. Jurnal Ekonomi Syariah Teori Dan Terapan, 3(1), 70-84.

Utami, H. (2017). Pengaruh Inflasi, Kurs Dan BI Rate Terhadap Nilai Aktiva Bersih Reksadana Syariah Di Indonesia. Jurnal An- Nisbah, 4(1).

Wijayanti, Y., \& Sudarmiani. (2017). Pengaruh Tingkar Inflasi Terhadap Nilai Tukar Rupiah (Studi Pada Bank Indonesia Periode Tahun 2011-2015). Jurnal EQULIBRIUM, 5(1), 32-44.

www.bi.go.id.

www.dsnmui.or.id.

www.ojk.go.id.

www.sam.co.id. 